\title{
Türk Siyasal Hayatında Danışma Meclisi
}

\author{
CENGIZ SUNAY \\ cengizsunay@hotmail.com \\ ORCID ID: 0000-0001-8205-7518
}

Öz: Türkiye'deki siyasal hayata yön ve biçim verme noktasında tekrar ede gelen bir alışkanlık var. Normatif düzenlemeler yoluyla toplumsal hayatın çeşitli kesimlerindeki aktör ve bağhlarının yönlendirilebileceği doğrultusundaki peşin hüküm, her altüst oluş sonrasında yeni bir anayasal sistemin teşkiliyle sorunlarm çözüleceği istikametinde. 1982 Anayasasını yapan irade, bu tespitin en somut örneği. Yetmişli yıllar boyunca bir türlü sağlanamayan, yönetimde istikrarı öne alıp, marjinal olarak tanımladığ kesimleri parlamento dışına atmayı hedefleyen seçim barajları eliyle merkezin temsiline dayalı bir siyasal sistemi öne alıyordu. Bu çalışmada, Türk siyasi hayatında en çok tartışılan ve cumhuriyet tarihinin en uzun anayasası olma unvanını, 1924 Anayasasından almaya az bir zaman kalan 1982 Anayasasının mutfă̆ı olan Danışma Meclisinin hukuki altyapısı, teşkili, çalışma düzeni ve üye profili üzerinde duruluyor.

Anahtar kelimeler: Türk Anayasaları, Danışma Meclisi, 12 Eylül Darbesi.

\section{Giriş}

Türkiye tarihinin en önemli kırılma noktasının hangi gelişme olduğu konusunda bir fikir birliği bulunmuyor. Siyasal hayatın tarafları bu hususta mensubu bulundukları safın çıkarları eşliğinde tezlerini ileri sürüyorlar. Konu anayasalı siyaset olduğunda kuşkuya yer bırakmayacak önemde olduğu düşünülebilecek olan gelişmenin Tanzimat Fermanı olduğu iddiası da en azından bu çalışmanın yazarının kanısı. Dönemi itibarıyla Tanzimat'ın sarsıcı bir soğuk düş etkisi var. Metni ilan etmek üzere Gülhane Parkı'na doğru yola çıkan Sadrazam Koca Mustafa Reşit Paşa’nın; akıbetinden endişeli olduğu; bir daha belki de evine dönememe kaygısı taşıdığı, kaynaklarda kayıtlıdır. ${ }^{1}$ Fermanın, millet sisteminde egemen olan Müslüman milletinin bundan böyle gayrimüslime gâvur denmesini bile yasakladığı şeklinde yorumlanmış ve bu açıdan bile bir tür hâkimiyet kaybı olarak algılanmıştı. ${ }^{2}$

\footnotetext{
* Dr. Öğr. Üyesi, Kocaeli Üniversitesi, İİBF, Siyaset Bilimi ve Kamu Yönetimi Bölümü.

1 Reşat Kaynar, Mustafa Reşit Paşa ve Tanzimat, Ankara: Türk Tarih Kurumu Basımevi, 2010, s.175.

2 Roderic N. Davison, Reform in Ottoman Empire 1856-1876, Princeton, New Jersey: Princeton University Press, 1963 , s.43.
} 
Tanzimat; yönetimin, kendi kendisini sınırladığı, iktidarına zayıf da olsa sınır çektiği siyasal bir metin ve bir dönemin başlangıcıdır; devri itibarıyla gayet önemlidir. Ardılı Islahat Fermanı, Tanzimat kadar yerli sayılmayabilir ancak her ikisi de ilk anayasalı yönetim hamlesi olan 1876 tarihli Kanun-i Esasi'ye giden yolun adeta parke taşlarıdır. ${ }^{3}$ Kanun-i Esasi, 1909 değişiklikleriyle 1slahı sonrasında 1921 Teşkilat-1 Esasiye’den 1924 Anayasası'na uzanan çizgi içinde Türk anayasa tarihinin evriminin en önemli aşamalarındandır. 1961 Anayasası'nın selefi 1924 Anayasasının ise yürürlükte olduğu yıllarda ve özellikle, muhalefetin tasfiye edildiği 1926 sonrasından 1937 değişikliklerine kadar; tatbikat ne olursa olsun, normatif olarak demokratik bir anayasa olduğu kabul edilmektedir. Söz konusu değişikliklerle birlikte, tek-parti ideolojisinin; daha otoriter, katı ve dışlayıcı nitelik aldığı; diğer devlet anlayışlarının sadece uygulamada değil, fikri planda da reddedildiği belirtilmektedir. Böylece, tek-parti sisteminin gelip geçici bir zorunluluk değil, ideal ve kalıcı bir model olarak takdim edildiği; Türklük ve Türk milliyetçiliğinin, sadece kültürel değil, etnik çağrışımlara da yer verecek şekilde kuvvetle vurgulandığı da iddia edilmektedir. ${ }^{4}$ Siyasal gelişmelerin belirleyiciliği ekseninde Türkiye, bu anayasayla çok partili siyasal hayata başladı ve malum trajik sonla; sadece bir dönem kapanmadı, militarizmin gölgesinde anayasa yapım süreci de başlamış oldu.

Altmışlı yıllardan itibaren, özellikle ellili yıllardaki gerilimin muhataplarından biri olan Demokrat Parti'den neşet etmiş siyasi partilerin hemen hepsinin ortak kanaati: Peşinen yürütmeyi mahkûm eden 1961 Anayasasının ruhuyla, ülkeyi yönetmenin mümkün olamayacağ doğrultusundayd $1 .{ }^{5}$ Nitekim 12 Mart Muhtırasının hemen ertesinde başlayan ve Türk siyasi hayatında ara dönem olarak isimlendirilen evrede, 1961 Anayasası geniş ölçüde budandı. Dönemin; CHP'den müstafi, başbakanı Nihat Erim tarafından ülke için son derece lükss addedilen anayasa, bir dizi değişikliğe tabi tutuldu. Yapılan değişikliklerle anayasanın özgürlükçü karakteri zedelendiyse de, bir bütün olarak anayasa, kör topal yine ortada duruyor; tüm bu değişikliklere rağmen anayasanın ruhundaki çok sesli ve hürriyetçi imge, yönetenler cephesine rahatsızlık vermeye devam ediyordu. ${ }^{7}$ Muhtıranın, görünüşteki baş; aslında en gönülsüz, imzacısı olan dönemin Genelkurmay Başkanı Org. Memduh Tağmaç, parlamento dışı muhalefet unsurlarına etkili muhalefet yapma imkânını veren bu anayasanın revize edilmesinin gerekçesini ise "Sosyal gelişme ekonomik gelişmeyi aştı" sözleriyle dile getiriyordu.

3 Stanford J. Shaw ve Ezel Kural Shaw, History of Otoman Empire and Modern Turkey, Volume II: Reform, Revolution and Republic: The Rise of Modern Turkey, 1808-1975, New York: Cambridge University Press, 2005, s.55 vd.

4 Ergun Özbudun, 1924 Anayasası, İstanbul: Bilgi Üniversitesi Yayınları, 2012, s.12.

5 William Hale, Turkish Politics and the Military, London and New York: Routledge, 1994, s.200-203.

6 Altuğ, bu lüks deyiminin, Erim'in yabancı basın mensupları huzurunda verdiği bir demecin içinde geçen bu tabiri, Altemur Kılıç’ın, özensizce çevirip basına dağıtmasıyla dillere persenk olduğunu aktarıyor. Bkz. Kurtul Altuğ, 12 Mart ve Nihat Erim Olayı, İstanbul: Baha Matbaası, 1973, s.56 vd.

7 Kapani’nin 1971 ve 1973 değişiklikleri konusundaki şu yerinde tespitini aktarmak gerekiyor: "12 Mart’ta iktidardan uzaklaşanlarla onları uzaklaştıranlar, Anayasayı suçlama çizgisinde ve onun mutlaka değiştirilmesi gerektiği görüşünde birleşiyorlardı”. Bkz. Münci Kapani, Kamu Hürriyetleri, Ankara: AÜ Hukuk Fakültesi Yayınları, 1981, s.128. Değişikliklere asıl ruhunu veren teşhis, 1961 Anayasasının yürütmeyi zayıflattığı temeli üzerine dayanıyordu, bkz. Bülent Tanör, Osmanlı-Türk Anayasal Gelişmeleri (1789-1980), İstanbul: Der Yayınları, 1995, s.348.

8 Aynı Tağmaç, zoraki emekliliği sonrasında Sanayi ve Kalkınma Bankası Yönetim Kurulu üyeliğine getiriliyordu, bkz. Uğur Mumcu, Sakıncalı Piyade, İstanbul: Tekin Yayınevi, 1977, s.37. 
Yetmişli yıllar boyunca tırmanan gerilimin sebebi olarak, aşırı özgürlükleri gösteren zevat açısından 12 Mart Muhtırası sonrasında yapılan değişiklikler yetersizdi. Ülkenin bu kez doğrudan bir müdahaleyle kalıcı otokrasinin icra sahası yapılmasının kurgulanması, özellikle, 1 Mayıs 1977 Taksim Olaylarıyla başlatılan güdümlü şiddet eylemleriyle mümkün oldu. ${ }^{9}$ Derin bir can kaygısı eşliğinde, toplumun en temel hak olan yaşam hakkı karşılığında; diğer sosyal, ekonomik ve siyasal haklarından feragat etmesi iradesini ortaya koymaya mecbur edilebilmesi için 12 Eylül Darbesinin kamuoyu desteğinin inşa edildiği iddia edildi. Bu süreç, bireysel katliamların önce sıradan militanlar, apolitik bireyler, tanınmış; yazar, öğretim üyesi, gazeteci, emekli yahut muvazzaf asker ve polisten; sonrasında, Çorum, Malatya, Maraş gibi kolektif vahşetler eşliğinde gelişti. ${ }^{10}$ Ekonomik buhranın tetiklediği gerilimi aşma doğrultusundaki 24 Ocak Kararları deklare edildiğindeyse böylesi bir programın yürütülmesinin, ancak ve ancak demokrasinin askıya alındığg bir ortamda mümkün olabileceği artık bir sır değildi. ${ }^{11}$

12 Eylül Darbesi, selefleriyle kıyaslanamayacak ölçüde lider kadrosuyla özdeş özellikler göstermiş bir askeri müdahale olarak temayüz ediyordu. Darbenin lideri, emekliliğin kapısından birkaç kez dönmüş, Kore kıdemi beklentisi olmadığı takdirde, general olmayı bile ummayan birisiydi. ${ }^{12}$ Türk ordu geleneğinde benzerine rastlanmayan şekilde Ege Ordusu da denilen 4. Ordu Komutanlığından; önce, Kara Kuvvetleri Komutanlığına, sonraysa Genelkurmay Başkanlığı’na gelen tek orgeneral olma istisnası olma durumu sürmektedir. Kuşkusuz Kenan Evren'in şahsının, ülkede bir darbe olmasını hızlandıran özelliği olduğu söylense de, burada aslolan: şahsi tutum ve anlayışının darbe sonrasında yaşananların üslubuyla olan ilgisidir. Evren; bir sağdan, bir de soldan asarak adaleti tesis ettiğine inanan adamdır. ${ }^{13}$ İdam kararlarını tasdik ederken elleri hiç titremeyen, asmak ve beslemek arasında tereddüt etmeden ilkini yapandır. Bu çalışmada, böylesi bir eğilimde olan şahsın ve etrafındaki kadronun yaptığı anayasanın adeta mutfağı olan Danışma Meclisi üzerinde durulacaktır.

\section{Danışma Meclisinin Teşkili Öncesi Yapılan Hazırlıklar: Anayasa Düzeni Hakkında Kanun}

Danışma Meclisi'nin teşkili öncesinde iki önemli yasal düzenleme bahis konusuydu. Bunlardan ilki: 27 Ekim 1980'de kabul edilen, 28 Ekim 1980'de Resmi Gazete'de yayınlanarak yürürlüğe giren 2324 sayıl Anayasa Düzeni Hakkında Kanundur. Zikredilen kanun, daha giriş cümlelerinden itibaren, hukukun temel kaidelerinin en başta gelenlerinden biri olan normlar hiyerarşisine riayet hilafına, senelerce darbelere yasal mesnet olarak ileri sürülen TSK İç Hizmet Kanunu'nun 35. maddesine gönderme yaparak, girişilen hareketin Türkiye Cumhuriyeti’ni koruma ve kollama harekâtı olduğu bir kez daha vurgulamaktadır.

9 Feroz Ahmad, The Making of Modern Turkey, London and New York: Routledge, 2002, s.169.

10 Ömer Laçiner, "Malatya Olayı-Türkiye'deki Faşist Hareketin Yapısı ve Gelişimi”, Birikim, Sayı 39, 1978, s.15-19. 11 Mustafa Sönmez, 100 Soruda Dışa Açılan Türkiye Kapitalizmi (1980’lerden 1990’lara), İstanbul: Gerçek Yayınevi, 1992, s.126 vd.

12 Uğur Mumcu, İnkılâp Mektupları, İstanbul: Tekin Yayınevi, 1993, s.152-157.

13 Murat Belge, 12 Yil Sonra 12 Eylül, İstanbul: Birikim Yayınları, 1992, s.27. 
Büyük Türk Milleti adına tarihi sorumluluk duygusu ile hareket ederek emir ve komuta zinciri içinde ve emirle 12 Eylül 1980 harekâtını gerçekleştirmiş ve yönetime bütünü ile elkoymuş bulunan Türk Silâhlı Kuvvetlerinin yönetime elkoymasını zorunlu kılan sebepler ile harekâtın amacı ve Milli Güvenlik Konseyinin kuruluş tarzı, Konsey bildirileri ve Konsey Başkanının 12 Eylül 1980 günü radyo ve televizyonla yayınlanmış konuşması ile kamuoyuna duyurulmuştur.

Saklanamayacak kadar hukuki meşruiyet eksikliğinin sıkıntısının hissedildiğinin aşikâr oluşu, daha, söz konusu kanunun 1. maddesiyle ortaya çıkmakta; anayasa gibi en üst hukukî belge, sıradan bir yasayla sınırlandırılmaktaydı. 1961 anayasasının, sair maddelerde belirtilen istisnalar saklı kalmak üzere yürürlükte olduğu ilân edilmekte; anayasaya aykırı olarak müdahale edenlerin, ilga ettikleri anayasaya referansa kısmen devam etmek mecburiyetinde oldukları görülüyordu.

Madde 1 - 9 Temmuz 1961 tarihli ve 334 sayılı Türkiye Cumhuriyeti Anayasası ile değişiklikleri, aşağıdaki maddelerde belirtilen istisnalar saklı kalmak üzere, yeni bir Anayasa kabul edilip yürürlüğe girinceye kadar yürürlüktedir.

2. maddedeki hüküm, modern demokratik anayasaların tamamında yer alan, hiçbir mercii yahut kurumun kaynağını anayasadan almadığı hiçbir yetkiyi kullanamayacağı ilkesine açık bir aykırılık içinde olunduğunu gizleyemiyordu. Beş kişilik ve eski sistemde Milli Güvenlik Kurulu’nun askeri kanadı olmak dışında hiçbir özelliği olmayan silahlı bürokrasi, meclis ve senatonun görev ve yetkilerini açıkça gasp ettiğini tescil; liderini, cumhurbaşkanı yerine ikame ediyor; bundan da hiçbir şekilde rahatsiz olmuyordu.

Madde 2 - Anayasada Türkiye Büyük Millet Meclisine, Millet Meclisine ve Cumhuriyet Senatosuna ait olduğu belirtilmiş bulunan görev ve yetkiler 12 Eylül 1980 tarihinden itibaren geçici olarak Milli Güvenlik Konseyince ve Cumhurbaşkanına ait olduğu belirtilmiş bulunan görev ve yetkiler de Milli Güvenlik Konseyi Başkanı ve Devlet Başkanınca yerine getirilir ve kullanılır.

Aslında darbecilerin hukuka hiçbir ihtiyaçları olmadığı gözüküyordu. Hukuki süreç ve olgular gözetilmeden yapılan düzenlemenin yaptırımla desteklense dahi meşru olamayacağı bilincinden uzak olanlar, yine de hukukla kayıtlı oldukları görüntüsünü vermek istiyorlardı. Bu çerçevede 3 . madde, cunta idaresinin aldığ 1 ve alacağ1; yayınladığ 1 ve yayınlayacağı karar ve bildirilerin anayasaya aykırılı̆̆ının ileri sürülemeyeceğini belirtiyor. Böylece, anayasaya bağlı kalınmayacağının açık itirafı olan bu hükümle, aslında 1. maddenin de iptali söz konusu olmaktadır.

Madde 3 - Milli Güvenlik Konseyince kabul edilerek yayımlanan bildiri ve karar hükümleri ile yayımlanan ve yayımlanacak olan kanunların Anayasaya aykırılı̆̆g iddiası ileri sürülemez.

4. ve 5. maddeler, idarenin her türlü eylem ve işlemlerine karşı yargı yolunu açan 
müktesebatı tamamen ortadan kaldırıyor; ${ }^{14} 1402$ Sayılı Sıkıyönetim Kanunuyla işinden olanların yargıya gidemeyecekleri sonucunu doğuran bu kararın uygulanmasıyla, alınan/alınacak kararlar lâfzıyla, hüküm daha bir muhkem hale getiriliyordu. Böylece, kamu personeli disiplin mevzuatının en ağır yaptırımı olan memuriyetten çıkarma şeklindeki ihraçların yoğun bir biçimde icrasının önü de açılmış oluyordu. Oysa bilindiği gibi Memurin Muhakematı Kanunu uyarınca memurlara tatbik edilecek cezaî işlem beş aşamadan oluşmaktadır. Bunlar: uyarma, kınama, aylıktan kesme, derece/kademe ilerlemesinin durdurulması ve memuriyetten çıkarmadır. Bu cezaları gerektiren fiiller, kanunda ve yerleşik içtihatlarda sayılmıştır. İdarenin cezai manadaki eylem ve işlemleri de asla yargıdan muaf değildir. Tahmin edileceği gibi, dönem içinde uygulanan bu cezaların hiçbir yargı denetimine tabi olmaması, telâfisi mümkün olmayan durumlar ortaya çıkarmıştır. ${ }^{15}$

Madde 4 - Milli Güvenlik Konseyinin bildiri ve kararlarında yer alan ve yer alacak olan hükümlerle 12 Eylül 1980 tarihinden sonra çıkarılan ve çıkarılacak olan Bakanlar Kurulu kararnamelerinin ve üçlü kararnamelerin yürütülmesinin durdurulması ve iptali istemi ileri sürülemez.

Madde 5 - 12 Eylül 1980 tarihinden sonra, Bakanlar ile Bakanların yetki verdiği görevlilerce kamu personeli hakkında uygulanan ve uygulanacak olan işlemlerin ve alınan kararların yürütülmesinin durdurulması istemi ileri sürülemez.

Anayasa değişiklikleri anayasaların uzlaşmayı en üst düzeyde aradıkları işlemlerden biridir. Anayasa değişikliği için salt çoğunluğu yetersiz kabul eden çoğu anayasa, nitelikli çoğunluk ismi verilen bir müessese tesis etmiştir. ${ }^{16}$ Katı anayasa geleneği olan Türkiye’de, özellikle 1961 ve 1982 Anayasaları özü itibarıyla, kurucu iradenin öz güven eksikliğini yansıtmaktadırlar. Bir anayasanın katı olmasını belirleyen başlıca üç özellikle teçhiz edilmiş olması gerekmektedir. Bunlar: anayasanın kimi maddelerinin değiştirilmesinin bile teklif edilmeyecek olması; değişiklik önergesi için önemli miktarda teklifte bulunan temsilci sayısının aranması ve değişikliğin salt çoğunluğun ötesinde bir ekseriyet eliyle yapilabilmesidir. ${ }^{17}$ Tüm toplumu etkileyecek olan muhtemel bir değişiklik hakkında uzlaşmayı en üst düzeye çıkarabilmeyi amaçlayan bu uygulama yok hükmüne indirgenmiştir. Beş asker, böylesine ciddî bir çekinceyi dahi dikkate almaksızın, "karar ya da bildirilerimiz anayasaya uymazsa yeni anayasa hükmü; kanuna uymazsa yeni kanun'dur”, diyebilmişlerdir.

Madde 6 - Milli Güvenlik Konseyinin Bildiri ve Kararlarında yer alan ve alacak olan hükümlerle Konseyce kabul edilerek yayımlanan ve yayımlanacak olan kanunların 9 Temmuz 1961 tarihli ve 334 sayılı Anayasa hükümlerine

14 Bu eğilim, 1982 Anayasasını da büyük bir oranda biçimlendirecek, anayasaya idare alanındaki yetkileri arttırmak, yargı denetimine yeni sınırlar koymak şeklinde yansıyacaktır. Bkz. Sait Güran, "Yönetimde Açıklık", İdare Hukuku ve İlimleri Dergisi (Sarıca’ya Armağan), 3/1-3 (1982): s.110.

15 Etraflı bilgi için bkz. Hüsamettin Kırmızıgül, Disiplin Suç ve Cezaları ve Denetim Yolları, İstanbul: Kazancı Kitap Ticaret AŞ, 1998.

16 Bu husus 1924 Anayasasında da geçerlidir. Bkz. Özbudun, 1924 Anayasası, s.73 vd.

17 Bkz. Hüseyin Nail Kubalı, Esas Teşkilât Hukuku Dersleri, İstanbul: Tan Matbaası, 1955, s.52 vd. 
uymayanları Anayasa değişikliği olarak ve yürürlükteki kanunlara uymayanları da kanun değişikliği olarak yayımlandıkları tarihte veya metinlerinde gösterilen tarihlerde yürürlüğe girer.

Son maddede, 28 Ekim 1980'de Resmi Gazetede yayınlanan kanunun yayın tarihine kadar geçen kırk altı günlük süreden bu yana geriye doğru da yürürlükte olduğu ifade ediliyordu. Kanunların resmi gazetede yayınlanmasıyla birlikte bağlayıcı olabileceği vaki iken, bir kanunun yürürlüğe girdiği tarih öncesini de kapsadığını beyan etmesi ancak hukuk dışı yönetimlere özgüdür. Bilindiği gibi Türk hukuk sisteminde neşir tarihiyle birlikte yasa koyucu ileri bir tarihten itibaren kaydını koyarak kanunun yürürlük noktasını tespit edebilir. Bu da ancak henüz gelmemiş bir tarih olabilir. Eğer hiçbir tarih belirtilmemişse, 28 Mayıs 1928 tarih ve 1322 sayılı yasanın 3. maddesi uyarınca resmi gazetede yayınlanan kanunun yürürlüğ̈̈, yayın tarihinden 45 gün sonra olarak kabul edilir. ${ }^{18}$

Madde 7 - Bu Kanun Resmi Gazetede yayımlandığında, 12 Eylül 1980’den itibaren yürürlüğe girer.

\section{Danışma Meclisinin Teşkili: Kurucu Meclis Hakkında Kanun}

Mevcut anayasanın karakteri mevcut oldukça, sıkıyönetim, olağanüstü hal gibi rejimler bilinen polisiye metotlarla yapılamazdı. Bu özelliği gören konsey, Anayasa Düzeni Hakkında Kanun'u yürürlüğe koyma ihtiyacı duymuş, yukarıda tam metni verilen kanunla darbenin en geniş yetkilerle donatımı sağlanmıştı. Yeni anayasayı yapmak üzere ihdas edilecek bir kurucu meclis için gerekli yasal çerçeve ise $29 \mathrm{Hazi}$ ran 1981 tarih ve 2485 sayılı Kurucu Meclis Hakkında Kanun ile sağlanıyordu.

1 Kasım 1980'de MGK Genel Sekreteri Haydar Saltık tarafindan düzenlenen basın toplantısı, ${ }^{19}$ MGK’nın önümüzdeki dönemdeki yol haritasının ana esaslarını ortaya koyuyordu. Saltık, konseyin aldığı ilke kararlarını şu şekilde özetliyordu: Kurucu meclisin teşkili için gerekli ön şartların hazırlanması; buna yönelik olarak çıkarılacak bir kanun; kurucu meclisin ilk işinin yeni anayasanın hazırlanması olduğu; ardından çıkarılacak referandum kanunu ile halkoyuna sunulacak anayasanın yürürlüğe girmesi. Anayasanın rehberliğinde yeni bir seçim ve siyasi partiler kanununun hazırlanması bu yasalar çerçevesinde kurulacak partilere teşkilâtlanmak için süre verilmesi; genel seçimlerin yapılarak TBMM'nin yeniden faaliyete başlaması; anayasa uyarınca şekillenecek olan TBMM ile birlikte kurucu meclisin ilga edilerek, yeniden çok partili siyasi hayata dönülmesi. ${ }^{20}$

18 Bkz. Abdullah Dinçkol, Hukukun Temel Kavramları, İstanbul: Der Yayınları, 2002, s.51.

19 Saltık MGK Genel Sekreterliğinin yanı sıra, Devlet Başkanlığı Genel Sekreterliği vazifesini de yürütüyordu, bkz. “Org. Saltık, Devlet Başkanlığı Genel Sekreteri Oldu”, Hürriyet, 22 Eylül 1980.

$20 \mathrm{Bu}$ yol haritasını hazırlayan Saltık, birçok isim tarafından, darbenin beyni olarak nitelendiriliyordu. Kahraman'ın ironik anlatımıyla 'ortalı̆̆ titretmesinden olacak, cezaevlerinde tutuklulara dayak atılan kalasımsı sopalara Haydar adı verilmişti”. Saltık’ın MGK üyelerinden sonra, altıncı önem derecesine sahip olmasına rağmen, Üruğa mağlûp olarak 1. Ordu Komutanlığından emekli olması ilginçtir. Bkz. Ahmet Kahraman, "Bana Evren Paşa Deyin”, İstanbul: Boyut Yayınları, 1989, s.48-49. Demirel ise Saltık’a en çok öfkelenenlerin başında geliyordu. Politikacı düşmanlığının Saltık tarafından konsey üyelerine telkin edildiği kanaatindeydi. Bkz. Hasan Cemal, Tank Sesiyle Uyanmak (12 Eylül Günlüğ̈̈), Ankara: Bilgi Yayınevi, 1986, s.355. 
Devlet Başkanı, 1980 yılını, 1981'e bağlayan yılbaşı mesajında takip edilecek yol haritasını açıkladı. Buna göre 1982 sonbaharında anayasa halkın tasvibine sunulacak; ertesi yılın sonbaharında ise genel seçimlere gidilecekti. Kurucu Meclis Hakkında Kanun, ikili tasnife tutulmuş olan Kurucu Meclis'in iki organı arasındaki ilişki biçimini açıkça gözler önüne koymuştur. Bu kanunun özü, asıl yasa koyucunun MGK olduğu, Danışma Meclisiyle aralarındaki ilişkinin tam anlamıyla bir ast-üst ilişkisi olduğunu, meclisin fonksiyonunun ismiyle müsemma sadece danışılacak, uygun bulunursa muvafik, bulunmazsa muhalif kalınıp tek taraflı olarak ilgili maddeyi resen saptayacak bir MGK istikametindeydi. Gerek yasa, gerek anayasa yapımında son söz hakkı ile hükümeti murakabe edecek tek mercii MGK idi. ${ }^{21}$

Kanunun başlangıcında Kurucu Meclis'in görevleri sayılıyor; görev süresi belirleniyordu. Buna göre Kurucu Meclis, Anayasa, ${ }^{22}$ Siyasi Partiler ve Seçim Kanunlarını yaptıktan sonra gidilecek genel seçimler ertesinde açılacak; TBMM fiilen göreve başlayıncaya kadar çalışacaktı. Kurucu Meclis'in yapısı iki organdan oluşuyordu. Bunlar; Milli Güvenlik Konseyi ve Danışma Meclisi olarak açıklanıyordu. Milli Güvenlik Konseyi bu yasayla daha önce elde ettiği TBMM, Millet Meclisi ve Cumhuriyet Senatosu'nun görev ve yetkilerini Danışma Meclisiyle birlikte kullanmaya başlayacaktı. Kurucu Meclis'in görevleri ise;

"Yeni anayasayı ve anayasanın halkoyuna sunuluş kanununu hazırlamak; hazırlanan anayasanın halkoyundan geçip kesinleştikten sonra geçici hükümlerine göre yürürlüğe girecek olan anayasa ilkeleri uyarınca, bir siyasi partiler kanunu hazırlamak. Hem anayasa hem de siyasi partiler kanunu hükümleri uyarınca bir seçim kanunu hazırlamak ve son olarak; genel seçimler yapılıp, TBMM fiilen göreve başlayıncaya kadar yasama görevini yerine getirmek" olarak sıralanıyordu. ${ }^{23}$

Kanunun ikinci başlığı Danışma Meclisi’ne ilişkin olarak yapılan düzenlemeleri kapsamaktaydı. Meclisin kalabalık tutulmak istenmediği üye sayısı belirlendiğinde ortaya çıkıyordu. Buna göre Danışma Meclisi toplam 160 üyeden müteşekkil olacaktı. Bu 160 üyenin 120'si, yasada her il için belirtilen sayının üç katı aday tespitiyle bizzat ilin valisinin inisiyatifi ile MGK'ya gönderilen adaylar arasından MGK tarafindan seçilecek; kalan 40 üye ise doğrudan MGK tarafından atanacaktı. ${ }^{24}$ MGK tarafından atanacak bu 40 üyeden üye olma şartlarını içeren koşullardan, yükseköğrenim yapmış olmak şartı aranmayacaktı. Diğer 120 üyenin sahip olması gereken niteliklerin tespitinde konulan kriterler ise şunlardı: TC vatandaşı olmak; otuz yaşını bitirmiş olmak, yükseköğrenim yapmış olmak; kısıtlı ya da kamu hizmetlerinden yasaklı olmamak; askerlik vazifesini yapmış ya da muaf tutulmuş olmak yahut mükellef olmamak; taksirli suçlar haricinde bir yıldan fazla hapis cezası almamış olmak; yüz kızartıcı suçlardan sabıkası olmamak ve son olarak 11 Eylül 1980 tarihi itibarı ile

21 MGK’nin sadece ana çerçeveyi belirlemediği hemen her yasayı bizzat ele aldığı bilinmektedir, bkz. "MGK, Gelir Vergisi Kanununda Değişiklikleri Görüştü”, Hürriyet, 18 Aralık 1980.

22 “Danışma Meclisi’nin Hedefi: Yeni Anayasa”, Milliyet, 17 Ekim 1981.

23 Bkz. "29 Haziran 1981 tarih ve 2485 sayılı Kurucu Meclis Hakkında Kanun”, m.2. 30 Haziran 1981 tarih ve 17386 Mükerrer Sayılı Resmi Gazete.

24 Bkz. "29 Haziran 1981 tarih ve 2485 sayılı Kurucu Meclis Hakkında Kanun”, m.3. 30 Haziran 1981 tarih ve 17386 Mükerrer Sayılı Resmi Gazete. 
herhangi bir siyasi partinin üyesi olmamak. ${ }^{25}$

Danışma Meclisine temsilci verecek, 67 vilâyet ve kontenjanları şöyle temsil ediliyordu: Adıyaman, Ağrı, Amasya, Artvin, Bilecik, Bingöl, Bitlis, Bolu, Burdur, Çanakkale, Çankırı, Edirne, Elâzığ, Erzincan, Eskişehir, Giresun, Gümüşhane, Hakkâri, Isparta, Kastamonu, Kırklareli, Kırşehir, Kütahya Mardin, Muğla, Muş, Nevşehir, Niğde, Rize, Sakarya, Siirt, Sinop, Tekirdağ, Tunceli, Uşak, Van, Yozgat dâhil olmak üzere 37 il 1 üyeyle temsil ediliyorlardı. Afyon, Antalya, Aydın, Balıkesir, Çorum, Denizli, Diyarbakır, Erzurum, Gaziantep, Hatay, İçel, Kars, Kayseri, Kocaeli, Malatya, Manisa, Kahramanmaraş, Ordu, Sivas, Tokat, Trabzon, Urfa olmak üzere 22 il 2; Bursa, Samsun ve Zonguldak illeri 3; Adana ve Konya 4, İzmir 5, Ankara 8, İstanbul 9 üyeyle temsil ediliyorlardı. ${ }^{26}$ Danışma Meclisinin teşkil biçimiyle, siyasi partilerin kapatılarak, köksüz ve uzlaşmasız bir anayasa hazırlı̆̆ı sürecine itiraz eden yazarların gazeteleri kapatillyordu. ${ }^{27}$

Üyeler ilk, orta, lise veya yükseköğrenimlerini yaptıkları illerden ya da aralıklı en az beş, aralıksız üç yıl oturdukları yahut son iki yıldan beri ikamet ettikleri ilin valiliğine başvuru yapıp, Danışma Meclisi üyeliğine aday adayı olabiliyorlardı. MGK'nın doğrudan atayacağ dilekçe ekinde adaylar başvuruda bulunabileceklerdi. Tüm başvurular gerekli silsileyi izleyerek MGK'ya ulaştırıldıktan sonra atananların isimleri resmi gazetede ve TRT'de yayınlanacaktı. Herhangi bir sebepten dolayı üyeliklerden biri ya da birkaçı boşaldığında, üyenin ilden önerilen veya doğrudan doğruya MGK tarafından atanan üye olup olmadığına bakılmaksızın yerine atanacak üyeyi MGK belirleyecekti. ${ }^{28}$ Evren, 40 üyenin doğrudan doğruya MGK tarafından atanacak olmasını, seçilecek asker kökenliler açısından istediklerini aktarıyor. Bu açıdan, valiliklere asker kökenlilerin seçilmemesini emrettiklerini, kamuoyunda hep asker olanı meclise soktular şeklinde bir dedikodunun oluşmamasını hedeflediklerini belirtiyordu. ${ }^{29}$

Üyeler daha önce kamu hizmeti ifa etmekte olsalar bile buralardan kendi istekleri dışında ilişikleri kesilmez, ücretsiz izinli sayılırlardı. Danışma Meclisi üyeliğinde geçirdikleri süreler terfilerinde ve emekliliklerinde hesaba katılacaktı. Üye olarak yemin ettikten sonra yapacakları her türlü açılama, kullanacakları her yöndeki oydan ötürü sorumlu tutulamayacak dokunulmazlığa sahip olacaklardı. Suçüstü hali dışında Danışma Meclisi’nin üye sayısının salt çoğunluğu kararı olmaksızın sanık sıfatını sokulamaz, yargılanamazlardı. Seçilmeden önce veya seçildikten sonra herhangi bir üye hakkında kesinleşmiş bir cezanın infazı, meclisin yasada yer alan biçimde göre-

25 Bkz. "29 Haziran 1981 tarih ve 2485 sayılı Kurucu Meclis Hakkında Kanun”, 30 Haziran 1981 tarih ve 17386 Mükerrer Sayılı Resmi Gazete. m.3. Danışma Meclisinin yurtdışında iyi karşılandığı haberini veren basın; tek iğneleyici yorumun İngiliz The Guardian'da yapıldığını bildiriyordu. Gazeteye göre; “Türk Meclisinde Sağ Taraf Ağır Basıyor”, bkz. Milliyet, 17 Ekim 1981.

26 Bkz. "29 Haziran 1981 tarih ve 2485 sayılı Kurucu Meclis Hakkında Kanunun” sonundaki iller ve üye sayılarını gösterir cetvel.

27 Hasan Cemal, Tank Sesiyle Uyanmak, s.401.

28 Bkz. "29 Haziran 1981 tarih ve 2485 sayılı Kurucu Meclis Hakkında Kanun”, m.11. Kenan Evren, Kenan Evren”in Anıları-2, İstanbul: Milliyet Yayınları, 1991, s.359.

29 Kenan Evren"in Aniları-2, s.359. 
vinin sona ermesine kadar tehir edilir; geçecek süre dava ve ceza da zamanaşımından sayılamazdı. Danışma Meclisi üyeleri görevlerini aksatmamak koşuluyla meslekî faaliyetlerine devam edebilirlerdi. Bu meslekî faaliyetler sadece özel işleriyle ilgili olabilir herhangi bir kamu tüzel kişiliğine sahip olan kuruluşta temsilcilik, hakemlik veya vekillik görevi alamazlard $1 .{ }^{30}$ Danışma Meclisinin gerek kuruluşu, gerekse işleyişi ile hazırladığı anayasanın son şekli itibarıyla Kurucu Meclis bünyesinin zayıf halkasını oluşturması nedeniyle irade sahibi değil, istişari bir organ olduğu aşikâr gibi gözükmektedir. ${ }^{31}$

Üyeliğin düşmesi ise şu koşullara bağlanıyordu: istifa, seçilmeye engel bir suçtan dolayı hüküm giyme ya da kısıtlanma, genel kurul ve komisyon çalışmalarına bir ay içinde özürsüz olarak toplam beş gün katılmama. Kamu kurum ve kuruluşlarında veya kamunun ortaklığı bulunan kuruluşlarda görev alma halinde de Danışma Meclisi Genel Kurulunca üyeliğin düşmesi kararı verilirdi. ${ }^{32}$ Danışma Meclisi üyeliğine getirilenler aylık ve ödenek bakımından çok iyi koşullara sahiplerdi. Genel olarak TBMM üyelerine tanınan tüm sosyal haklardan yararlanma hakkına sahiptiler. ${ }^{33}$ Meclis göreve başladığında önceki meclislerde olduğu gibi ilk toplantıda en yaşlı üye başkanlık, en genç iki üye de kâtiplik görevi yapacaklard $1 .{ }^{34}$ Yemin merasiminde okunacak metin ise şu şekilde belirlenmişti:

Danışma Meclisi üyesi olarak çalışmalarımda Devletin varlığı ve bağımsızlığ1n1, ülkenin ve milletin bütünlüğünü ve bölünmezliğini koruyacağıma, toplumun huzuru, milli dayanışma ve sosyal adalet anlayışı içinde herkesin insan haklarından temel hürriyetlerden yararlanması ülküsünden ayrılmayacağıma; hukukun üstünlügünü sağlayacak demokratik ve lâik Cumhuriyet ilkelerine bağlı kalacağıma namusum ve şerefim üzerine andiçerim. ${ }^{35}$

\section{Danışma Meclisi'nin Çalışma Düzeni}

Tüm bu seçim (!) süreçleri sonucunda üyeler belirlendi. İlk toplantıyla birlikte Danışma Meclisi Başkanlık Divanı seçimi yapılacaktı. Divan, bir başkan, iki başkan vekili, dört kâtip ve iki idareci üyeden oluşuyordu. İlk toplantıdan sonra 30 gün içinde 15 kişilik Anayasa Komisyonu kuruldu ve başkanlığına İstanbul Üniversitesi Hukuk Fakültesi Anayasa Hukuku Kürsüsü öğretim üyelerinden Prof. Dr. Orhan Aldıkaç-

30 Bkz. 29 Haziran 1981 tarih ve 2485 sayılı Kurucu Meclis Hakkında Kanun, m.15. Bülent Tanör, İki Anayasa 1961-1982, İstanbul: Beta Basım, Yayım Dağıtım AŞ, 1986, s.99-107.

31 Tanör, İki Anayasa 1961-1982, s.99-107.

32 Bkz. 29 Haziran 1981 tarih ve 2485 sayılı Kurucu Meclis Hakkında Kanun, m.16. 30 Haziran 1981 tarih ve 17386 Mükerrer Sayılı Resmi Gazete.

33 Bkz. 29 Haziran 1981 tarih ve 2485 sayılı Kurucu Meclis Hakkında Kanun, m.17. 30 Haziran 1981 tarih ve 17386 Mükerrer Sayılı Resmi Gazete.

34 Bkz. 29 Haziran 1981 tarih ve 2485 sayılı Kurucu Meclis Hakkında Kanun, m.18. 30 Haziran 1981 tarih ve 17386 Mükerrer Sayılı Resmi Gazete.

35 Danışma Meclisi Tutanak Dergisi, Cilt 1; 1 nci Birleşim 23 Ekim 1981 Cuma, Toplantı Yılı 1981/1, s.1. 
$t \imath,{ }^{36}$ yardımcılığına ise Prof. Dr. Şener Akyol getirildi. ${ }^{37}$ Anayasa Komisyonunun diğer üyeleri ise şu isimlerden oluşuyordu: Kemal Dal, Muammer Yazar, Feyzi Feyzioğlu, Feyyaz Gölcüklü, Mümin Kavalal, Feridun Ergin, Turgut Tan, Rafet İbrahimoğlu, İhsan Göksel, Tevfik Fikret Alpaslan, Hikmet Altuğ, Teoman Özalp ve Recep Meriç.

İbrahimoğlu'nun Türkiye İşveren Sendikaları Konfederasyonu Genel Sekreteri, iki üyenin emekli korgeneral, son üçünün ise herhangi bir hukuk formasyonunun olmaması ilginçti. ${ }^{38}$ Genel Kurul çalışmalarıyla komisyon çalışmaları arasında önemli bir fark vardı. İlki açık olarak yapılırken ikincisi kapalı yapılıyordu. Ancak genel kurulda da salt çoğunluğun karar alması durumunda oturumlar kapalı yapılabilirdi. Genel Kurul toplantılarının açık olanlarındaki görüşmeler zapta geçiriliyor ve Tutanak Dergisinde yayımlanıyordu. Meclisteki toplantı yeter sayısı 81'di, yani salt çoğunluk olan meclis üye sayısının yarısından bir fazlası. Aksine hüküm bulunmayan durumlarda da toplantıya katılanların salt çoğunluğuyla karar veriliyordu. ${ }^{39}$

Kanun teklifi yapma yetkisi MGK üyeleri, Bakanlar Kurulu ve Danışma Meclisi üyelerine aitti. Danışma Meclisi üyelerinin kanun tekliflerinin gündeme alınabilmesi için söz konusu teklifin altında en az 10 üyenin imzasının bulunması gerekir. Tekliflerin yapıldığı mercii Danışma Meclisi Başkanlığıdır. Gerek Bakanlar Kurulundan gerekse meclis üyelerinden gelen kanun teklifleri, ilgili komisyon veya komisyonlarda görüşüldükten sonra Genel Kurula havale ediliyordu. Aynen ya da kısmen kabul edilen veya reddedilen tasarı ve teklifler MGK'ya intikal ettiriliyordu. Nihaî mercii MGK idi. Komisyonlarda teklif görüşülürken teklif sahibi Bakanlar Kurulu ise ilgili bakan ya da görevlendirdiği bir kimsenin; meclis üyeleriyse teklifin altında bulunan en az 10 imza sahibinden yine en az birinin; MGK üyelerinden biriyse MGK Genel Sekreterliğinden görevlendirilecek yetkili bir kişinin hazır bulunması gerekiyordu. Danışma Meclisinden gelen kanun tasarı ve teklifleri MGK tarafından aynen veya kısmen kabul edilebilir ya da reddedilebiliyordu. Konseyin kabul ettiği kanun metni resmi gazetede yayımlanarak yürürlüğe giriyordu. ${ }^{40}$

Yeni anayasa metni anayasa komisyonu tarafindan hazırlanarak genel kurula sunulacak. Genel Kuruldaki görüşmeler neticesinde son şeklini alan anayasa MGK’ya arz edilecek. Konsey, söz konusu metni değiştirebilir yahut aynen kabul eder; resmi gazetede yayımlanmak üzere halkoyuna sunulacak metin kamuoyunun görüşüne tevdi edilecek. Halk oyunun neticesi sonrası kesinleşecekti. ${ }^{41}$

36 Aldıkaçtı, kendisiyle yapılan bir söyleşide, üstü örtülü olarak 1969'daki ortanın solu politikasına gelene kadar CHP’ye bundan sonrasındaki tüm seçimlerde ise Feyzioğlu’nun CGP'sine oy verdiğini söylüyor. Askerlerin Feyzioğlu tutkusuyla çakışan bir tercih. Bkz. Ahmet Kahraman, İşte Biz (Röportajlar ve Portreler), İstanbul: Kaynak Yayınları, 1984, s.163.

37 Aldıkaçtı’nın basına yakınması, anayasanın hangi şartlarda hazırlandığını gösteren çok çarpıcı bir örnektir. "Şu anda en büyük güçlüğüm, demokratik bir anayasayı demokratik olmayan bir ortamda yapmaktan kaynaklanıyor”. Bkz. Cumhuriyet, 9 Mayıs 1982'den aktaran, Tanör, İki Anayasa 1961-1982, s.105.

38 Yavuz Donat, Buyruklu Demokrasi 1980-1983 (Yavuz Donat'in Vitrininden-2), Ankara: Bilgi Yayınevi, 1987, s.237-238.

39 Bkz. 29 Haziran 1981 tarih ve 2485 sayılı Kurucu Meclis Hakkında Kanun, m.22. 30 Haziran 1981 tarih ve 17386 Mükerrer Sayılı Resmi Gazete.

40 Bkz. 29 Haziran 1981 tarih ve 2485 sayılı Kurucu Meclis Hakkında Kanun, m.24 ve 25. 30 Haziran 1981 tarih ve 17386 Mükerrer Sayılı Resmi Gazete.

41 Bkz. 29 Haziran 1981 tarih ve 2485 sayılı Kurucu Meclis Hakkında Kanun, m.26. 30 Haziran 1981 tarih ve 17386 Mükerrer Sayılı Resmi Gazete. 
Bütçenin kabulü noktasında Danışma Meclisi; Bakanlar Kuruluyla, MGK arasında bir köprü vazifesi görüyordu buna göre; genel ve katma bütçe tasarılarıyla milli bütçe tahminlerini gösteren rapor, malî yılbaşından en geç üç ay önce Danışma Meclisine sunuluyordu. Meclis bütçe üzerindeki çalışmaları iki ay içinde tamamlamak zorundaydı. Bütçe Komisyonlarında kabul gören bütçe tasarıları Genel Kurula intikal ettirilerek karara bağlanır; ardından nihaî onay mercii olan MGK’ya gönderilirdi. Danışma Meclisindeki üyeler mevcut bütçe tasarısının içeriğindeki kalemlere ilişkin olarak, gider veya gelir üzerinde arttırıcı yahut azaltıcı teklifte bulunamazlardı. Burada da bütçenin kesinleşmesi için Danışma Meclisi’nin onayladığı bütçenin MGK tarafından da onaylanıp, kesinleşmesi ve malî yılbaşından önce resmi gazetede yayımlanması gerekirdi. Danışma Meclisiyle Milli Güvenlik Konseyi’nin gerek tüzel kişiliklerine, gerekse üyeleri aleyhine işlenen suçlar hakkında Türk Ceza Kanunu'nun TBMM ve TBMM üyeleri aleyhine işlenen suçlar başlığı altında düzenlenen hükümler tatbik edilirdi. ${ }^{42}$

27 Mayıs 1960 darbesinden sonra oluşturulan Temsilciler Meclisiyle kıyaslandığında, Danışma Meclisinin hem terkip, hem de yetki yönünden çok homojen ve çok zayıf kaldığ gözlenmekteydi. ${ }^{43}$ Bir kere Temsilciler Meclisi yanlış da olsa, iddia ettiği "icraatıyla demokrasiyi ortadan kaldırma teşebbüsünde bulunmuş, gayrimeşru olmuş" Demokrat Parti'yi ve onun temsil ettiği kesimleri, meslek örgütlerini bu sürece dâhil etmeyerek tutarlı davranmıştır. Çeşitli meslek kuruluşları, işçi ve işveren kesimleri, DP dışındaki partilerden üye almıştır. Dolayısıyla ortaya çıkan anayasa belki de bu durumdan ötürü, tüm hürriyetçiliğine rağmen \% 39 gibi bir ret oyuna muhatap olmuştu. ${ }^{44}$ Oysa Danışma Meclisi atamayla kurulmuş, bir anlamda emre amade bir oluşum olarak tebarüz etmiştir. Dikkat edilirse 15 Ekim 1981'de üyeliklere atananlar ilân edildiğinin hemen ertesinde yukarıda tam metni verilen, 16 Ekim 1981 tarih ve 2533 sayılı Siyasi Partilerin Feshine Dair Kanun ile tüm siyasi partiler kapatılmış; mal varlıkları ise hazineye devredilmişti. İleri sürülen gerekçe, meclis üyelerinin partilerin etkisi altında kalmalarını önlemekti. Partilerin kapatılması, yeni düzen içinde askerlerin beklentisi doğrultusunda siyaset yapacak güdümlü politikacılar yaratılması için yapılan, bir mıntıka temizliği olarak tanımlanabilir. ${ }^{45}$

Danışma Meclisinin Evren'in, dolayısıyla MGK’nın telkini doğrultusunda çalıştırılacağı zaten teşkilinden belliydi: ancak ufak da olsa üyelerin inisiyatif kullanabilecekleri beklentisi mevcuttu. Bu beklenti Evren’in meclisin açılış merasiminde yaptığı konuşmayla ortadan kayboldu. Evren âdeta yapılacak anayasanın ana hatlarını dikte

4229 Haziran 1981 tarih ve 2485 sayılı Kurucu Meclis Hakkında Kanun, m.27, 28 ve 30. 30 Haziran 1981 tarih ve 17386 Mükerrer Sayılı Resmi Gazete.

43 “2. Cumhuriyetin Temeli Dün Atıldı. Devrimden 225 Gün Sonra Meclis Açıldı”, Akşam, 7 Ocak 1961. Türk Anayasa Hukukunun 1961 Anayasası ekseninde gelişimiyle ilgil en yetkin eserlerden birini de kaleme almış olan Aldıkaçtı'nın şu eseri de takip edilebilir. Orhan Aldıkaçtı, Anayasa Hukukumuzun Gelişmesi ve 1961 Anayasası, İstanbul: İÜ Yayınlarından No: 1850; HF Yayınları No: 413, 1973.

44 Sami Küçük, "Atatürk ve 27 Mayıs", Nusret Kuruosman, Çeşitli Cepheleriyle Atatürk (Seri Konferanslar), İstanbul: İstanbul Matbaası, 1964, s.185-196.”Temsilciler Meclisi Kanunu”, 4. Tertip Düstur, cilt: 1, s.754; 16.12.1960 tarih ve 10682 sayılı Resmi Gazete. 45 Evren'in şu cümleleri aslında her şeyi özetliyordu: “Türkiye’de kurulacak demokrasiye yeni partilerle başlamak maksadıyla eski partiler feshedildi”, bkz. Milliyet, 17 Ekim 1981. 
ediyordu. "Kişi özgürlüğü diyerek devlet güçsüz bırakılamaz; güçlü bir Cumhurbaşkanlığı müessesi tesis edilecek; Cumhurbaşkanının seçilememesi halinde meclisin istikbalini belirleyecek önleyici hükümler getirilmelidir; yargı, idarenin icraat yapmasına engel olacak yorumlar yapmayacaktır; toplantı ve gösteri yürüyüşlerinin maksadından uzaklaştırılarak komünizme teşne kesimlerin elinde, devlete kafa tutma nümayişlerine dönüşmesine engel olunacaktır; anayasaya son halini biz vereceğiz." şeklinde özetlenebilecek ana başlıklarla dolu konuşması, bir anlamda nasıl bir anayasa yapılacağını ortaya koyuyordu. ${ }^{46}$ Yani, 1982 Anayasasında hiçbir sürprize yer olmayacaktı.

Danışma Meclisi kurulduktan sonra MGK'nın elinde tuttuğu yasa teklif ve tasarılarından bir kısmını meclise intikal ettirmesi ilginç değildi belki ama ilginç olan Sendikalar, Toplu İş Sözleşmesi, Grev ve Lokavt Kanunlarıyla, yargı ile ilgili kanun tasarılarını kendi uhdesinde tutmasıydı. MGK üyesi bulunan beş, genel sekreteri olan bir orgeneral; hangisi gönüllü, hangisi zoraki olduğu tartı̧̧ılabilir sayıdaki uzmanlarla birlikte kendini her işte mahir görüyor; "her şeyin en doğrusunu ve iyisini ben bilirim" diyordu. Siyasetten arındırıldığına inandıkları böyle bir mecliste bile bir müddet sonra başlayacak gruplaşmalar elbette ki entelektüel idrakleri kısıtlı cuntacıları hayretler içinde bırakacaktı. Cuntacılar, insanın olduğu yerde siyasetin de olacağını, bunun da kötü bir şey olmadığını algılayamıyorlardı. Sadi Irmak gibi Atatürkçülüğü tescilli bir ismi başkan yapmanın anlamını idrak etmiş bir meclis bekliyorlardı. ${ }^{47}$ Güdümlü bir meclis bile olsa Danışma Meclisìnin bile içinden zamanla ayrılıklar çatı̧̧malar oldu. Süreç içinde Evren, kimi zaman Irmak ile birlikte iki başkanvekili olan Fenni İslimyeli ve Vefik Kitapçıgil'i çağırarak durumdan memnuniyetsizliğini bildirdi. Böylesine siyasi gruplaşmalar ortadan kalkmadığı takdirde, bizzat dilekçeyle başvurarak üye olmak isteyen bu densizlere hadlerini bildireceklerini; gerekirse Danışma Meclisini bile feshedebileceklerini söyledi. ${ }^{48}$ Konsey, ileride siyasi faaliyetlere izin verdiğinde bizzat Danışma Meclisi’ne atadığı, siyasi partilere giren bazı üyeleri veto ederek tepkisini gösterdi. ${ }^{49}$

\section{Sonuç}

Danışma Meclisi’ne üye olmak için yapılan başvurular beklendiğinden fazla oldu. Öyle ki tüm ülke genelinde toplam başvuru sayısı 6000'i bulmuş, 15 Ekim 1981 tarihi itibarıyla valiliklerin belirlediği temsil edilecek aday sayısının üç katı olan adaylarla, MGK’nın doğrudan atayacağı üyelikler için müracaat eden adaylar arasından ilk gruptakilerden 120; ikinci gruptakilerden de 40 kişi üye olarak atanmışlardı. Yasa gereği yükseköğrenim görmüş olma şartının MGK tarafından atanacak adaylar için

46 Danışma Meclisi Tutanak Dergisi, Cilt 1; 1 nci Birleşim 23 Ekim 1981 Cuma, Toplantı Yılı 1981/1, s.2-6. 47 Sadi Irmak gerçekten de ilginç bir kişilikti. Tıp öğrenimi yapmasına rağmen, Kuran-1 Kerim’in mealini de yapmış, yaptığı meal Akşam Gazetesi tarafından satışa sunulmuş ve yaklaşık yüz küsur bin adet satmıştı. Bkz. Celâlettin Çetin, İşte Babıâli (Çuvaldızı Kendimize), İstanbul: Cem Yayınevi, 1991, s.100.

48 Yalçın Doğan, Dar Sokakta Siyaset, İstanbul: Tekin Yayınevi, 1985, s.164.

$49 \mathrm{Bu}$ isimlerin en başında, partilerin kurulmasına izin çıktıktan sonra, Muhafazakâr Parti adındaki partinin kurucu genel başkanlığını üstlenen, Danışma Meclisinin acar üyelerinden biri olan Mehmet Pamak ile bağımsız milletvekili adaylı̆̆ veto edilen Tunceli temsilcisi Kamer Genç gelmekteydiler. Bkz. Hulusi Turgut, 12 Eylül Partileri (Bir Dönemin Perde Arkası), İstanbul: ABC Ajansı Yayınları, 1986, s.398. 
geçerli olmamasına rağmen MGK, tercihini ağırlıklı olarak yükseköğrenimlilerden yana kullanmış, atayacağ 10 üyenin 37’sini yükseköğrenimliler arasından seçmişti. ${ }^{50}$ Böylece Danışma Meclisi 157 yükseköğrenimli, 3 de yüksek tahsil görmemiş üyeden teşekkül etmiştir. Devlet memuru olanların miktarı üyelerin yarısını oluşturuyordu; asker kökenliler mecliste beşte bir oranındayken, tüm meclisin yaş itibarıyla dörtte üçü 50 ve üzeri yaşlardan üyelerle doldurulmuştu. Danışma Meclisinin bu kompozisyonuyla toplumsal kesimlerin eğilim ve beklentilerini temsil ettiği tabiî ki söylenemezdi. ${ }^{51}$

Danışma Meclisi’nin üye yapısının baskın boyutunu oluşturan devlet memurlarının kuşkusuz birer siyasi kimliği vardı. Nitekim zaman içinde Meclisteki kimi oturumlarda kürsüde görüşlerini açılayan üyelerin siyasi yelpazenin neresinde durdukları konusunda ipuçları bulunabiliyordu. Bu şekilde birbirlerini bulan üyeler zaman içinde toplantılar yapmaya kadar varabilen birliktelikler kurmaya başlamışlardı. Bu toplantıların konseyin kulağına gitmesi; ardından başkanlık divanı üyelerinin bizzat Evren'den işittikleri azar üstüne eklenince; meclis içinde yarı resmi bir inceleme bile yapıldı. 160 üye beşer, onar kişilik gruplar halinde hafif bir sorgulamadan geçirildiler. Lâkin üyeler, birbirlerini tanıma noktasında o kadar yavaş seyreden bir süreç içindeydiler ki, ileride tamamen birbirlerinden ayrı dünya görüşlerine sahip oldukları bilinen Mehmet Pamak, Kamer Genç, Yıldırım Avcı ve Özer Gürbüz gibi isimler birlikte hareket edebiliyorlardı. Bu durum karşısında, Danışma Meclisinin en popüler isimlerinin başında gelen Anayasa Komisyonu Başkanı Prof. Aldıkaçtı bile sonunda patladı. Aldıkaçtı, ne kadar siyasetten ve siyasi partilerden arındırılmış meclis görüntüsü verilmeye çalışılırsa çalışılsın, Danışma Meclisindeki her bir üyenin aslında birer siyasi parti hüviyetinde olduğunu, birkaç partinin temsilcilerinden oluşacak bir meclisten kaçınılırken 160 partili bir meclis ortaya çıktığını söyleyiverdi. ${ }^{52}$ Tabi ki bu sözler karşısında konseyin tutumu beklendiği gibi menfiydi. Bizzat Evren tarafından; sarf ettiği sözlerden ötürü kınanan Aldıkaçtı yılmıştı, çekilip üniversitedeki görevine dönmeyi istiyordu. ${ }^{53}$

1945 meclisinde Çiftçiyi Topraklandırma Kanunu Tasarısı nasıl CHP’nin ortadan ikiye bölünme sürecini başlattıysa; 1981'in Danışma Meclisindeki ilk siyasi gruplaşma da benzer bir tasarı yüzünden meydana geldi. Devlet Bakanı İlhan Öztrak başkanl1ğındaki bir ekip tarafından hazırlanan tasarıyla, on yıldır kendilerine tahsis edilen 16 bin köylü ailesinin, zilyetliğindeki toprağın zilyetlik süresinin uzatılması gündeme getiriliyor; Danışma Meclisinde başını Orhan Aldıkaçtı ile Şener Akyol'un çektiği bir

50 Tanör, “Siyasal Tarih (1980-1995)”, Yay. Yön. Sina Akşin, Çağdaş Türkiye 1908-1980, C. 5, s.38.

51 Tanör, "Siyasal Tarih (1980-1995)", s.38-39. Anayasa hazırlama faaliyetinin odağı konumundaki kurucu iktidarın teorik niteliği hakkındaki mükemmel çalışma için bkz. Kemal Gözler, Kurucu İktidar, Bursa: Ekin Kitabevi Yayınları, 1998.

52 Doğan’ın aktarımıyla Aldıkaçtı’nın sözleri şöyleydi: "Danışma Meclisinde sıkıntı siyasi partilerin bulunmayışından kaynaklanıyor... 160 üyenin hepsi ayrı ayrı ve kendi başına bir siyasi parti hüviyetindedir". Doğan, Dar Sokakta Siyaset, s.165.

53 Aldıkaçtı’nın meclis içindeki gruplaşmalar üzerine bir de Evren'den uyarılar üstüne uyarılara muhatap olması, gerçekten kendisini yıldırmıştı. Oysa hazırlanan anayasanın muhteviyatı üzerine henüz gerçek tepkilerin ortaya çıkmasına müsait bir zemin bile yoktu. Soysal, belki de bu tip çalkantıları bilerek ortalığın bulandırılmaması telkinlerine karşı önemli bir uyarıda bulunuyordu: "Ortalık şimdi birazcık bulanmazsa, sonra çok daha fazla bulanır”. Bkz. Mümtaz Soysal, Demokrasiye Giderken, İstanbul: Hil Yayın, 1982, s.78. 
grup tarafından, tasarının kutsal mülkiyet hakkını ihlâl anlamına geldiği düşüncesiyle karşı çıkılıyordu. Tasarı üzerinde isim okunarak yapılan oylamayla 25 oy farkla tasarı kanunlaşıyordu. Tasarıya red oyu verenler meclisin sağ çekirdeği olurken; kabul oyu verenler sol çekirdeğini oluşturmuş oluyorlard1. ${ }^{54}$

Orhan Aldıkaçtı, karşı grubun bu oylamayla temayüz etmiş olduğu düşüncesiyle, toparlanmak gerektiği fikrini ileri sürerek kendilerine Atatürkçü Liberaller ismini veren bir grubun ilk toplantısını tertip etti. Tertip edilen toplantıda Aldıkaçtı, biran hızını alamayarak sürekli hale dönüştürmeye niyetli olduğu toplantıların belki de ileride kuracakları bir partinin çekirdeği olabileceği fikrini ortaya atınca, bu fikir, gelecekte kerhen de olsa Doğru Yol Partisi Genel Başkanlığına getirilecek olan Yıldırım Avcinın korkuyla karışık telâşına neden oldu. Avcı, böylesi bir girişimin konseyin kulağına gitmesi halinde, bir gece yarısı evlerinden toplanmalarının, işten bile olmayacağını ileri sürüyordu. ${ }^{55}$ Atatürkçü Liberaller bir dizi toplantının ardından meclisin yaklaşık dörtte biri demek olan 40 kişilik bir ekip haline geldiler.

Partileşme konusundaki ısrarlı tutumunu sürdüren Aldıkaçtı'nın bu çabalarını hayalî bulan birçok üye vardı. Siyasi Partilerin Feshine Dair Kanun'un, istediği kadar partilerin kapısına kilit vurup, mallarını hazineye irad kaydetsin; partilerin ve partililerin dimdik ayakta oldukları vurgusunu yapan kimi üyeler, partileşmenin ancak tabanı peşlerinden sürükleyen liderlerin icazetiyle kurulabileceğini, aksi takdirde kurulanın bir tabelâ partisi olmaktan öteye gidemeyeceğini savunuyorlard1. ${ }^{56}$ Sonunda bu kanaat de kabul gördü ve bu doğrultuda çalışma kararı alındı. Bu arada Atatürkçü Liberaller grubunun toplantılarına katılan üye sayısı 70’i bulmuştu.

Tüm bu gelişmelerden konseyin elbette ki haberi vardı. Meclis Başkanlık Divanı tarafından yapılan sorgulamalar, iş tam da böylesine dallanıp budaklandıktan sonra yukarının emriyle yapılmaya başlandı. Aldıkaçtı, bu sorgulamalarda hiçbir şeyi gizlemiyor; meclisin ne kadar inkâr edilse de kendisini siyasetten soyutlayamayacağını belirtiyor; "böylesi bir çatı altında gruplaşma olmayacak da nerede olacak?" Sualini soruyordu. ${ }^{57}$ Tarihin garip bir cilvesidir ki, Aldıkaçtı gibi muhafazakar olarak nitelendirilen bir şahıs bile açıkça askerlere rağmen meclis içinde siyasi gruplaşmaların olmasını doğal karşılarken, kendisini solcu, sosyal demokrat olarak tanımlayan ve ileride bir kez hariç hep bu tip partilerde ve parlamentoda eksik olmayacak olan Kamer Genç, yaptıklarının yanlış olduğunu iddia edebiliyordu. ${ }^{58}$ Tüm bu tartışmalarda taraf olanlardan bazılarına göre bu tür çabalar siyasi ikbal peşinde olmanın mahsulleriydi ve bunun önüne geçebilmenin tek yolu Danışma Meclisi üyelerinin demokrasiye geçildikten sonra yapılacak ilk genel seçimde parlamenter olmalarının engellenmesiydi. Kurucu Meclis Yasasına eklenecek bir maddeyle bu iş kökünden uyarınca CHP tarafından işletilen para, hisse senetleri ve taşınmazlar artık Devlet Başkanlığı Genel Sekreterliğince idare edilecekti ama partilerin ruhu, anayasa ve siyasi partiler kanunu kabul edildikten sonra başka partilerin bedenlerinde yaşamaya devam edecekti, bkz. Milliyet, 17 Ekim 1981.

57 Doğan, Dar Sokakta Siyaset, s.170.

58 Doğan, Dar Sokakta Siyaset, s.172. 
halledilirdi. Yine ne gariptir ki bu öneri MGK’ne kadar götürülecek ancak konsey bunun gereksiz olduğuna hükmedecektir. ${ }^{59}$

Aldıkaçtinın bu işteki cesareti doğrusu hayret vericidir. Anayasa Komisyonu Başkanı olarak başkanlık divanındaki tutanaklı sorguda söylemeyi unuttuğu bir cümleyi meclis koridorunda Irmak ve Kitapçıgil’in yüzüne haykırırcasına söyleyebilen bir Aldıkaçtı vardı. Üstelik söylediklerinin tutanaklara geçmesini isteyerek: "siz kim oluyorsunuz da burada bizleri yargilıyorsunuz; toplantı da yaptım, bundan sonra da yaparım."60

Danışma Meclisi üyeleri hakkında istihbarat yapanlar sadece konsey üyeleri ve onlar adına meclis başkanlık divanı değildi. Özellikle, kapatılan Adalet Partisi’nin genel başkanı Süleyman Demirel, kurmaylarına üyeler hakkında bilgi toplama emri veriyordu. Demirel'e göre siyasetin tadını almış; siyasi hırsın nasıl bir şey olduğunu anlamış bu isimler bir gün gelecek kendilerinin de kapılarını çalacaklardı. ${ }^{61} \mathrm{Bu}$ isimler Demirel'in beklediğinden erken geldiler; Demirel'den beklentileri vardı ama ağızlarındaki baklayı bir türlü çıkarmıyorlardı. Açıkça "biz siyasete gireceğiz tabanınıza muhtacız, bu yüzden bizim lehimize bir işaret verir misiniz?” Diyemiyorlardı. Demirel tüm olup biteni anlıor ve kendilerine sadece "şimdilik size verilen görevle meşgul olunuz göreviniz yeni bir anayasa yapmaktır" cevabını veriyordu. Demirel temkinli hareket etmeyi siyasi ilkelerinin başköşesine oturtmuş bir siyasetçiydi. Yapılanın ne 27 Mayıs, ne de 12 Mart olmadığını biliyor; ne yardan ne serden vazgeçmemecesine bir taraftan örgütünü etrafında tutuyor; diğer taraftan da askeri tahrik edecek davranışlardan ısrarla kaçınıyordu.

Danışma Meclisinin merkezkaç tavırlar içine girmesinin ilk belirtilerinden biri de, meclisin acar üyelerinden Mehmet Pamak'ın İçişleri Bakanı Selahattin Çetiner ${ }^{62}$ ile Milli Eğitim Bakanı Hasan Sağlam’ın istifasını istenmiş olmasıydı. Her ikisi de emekli general olan (Çetiner E. Korg. Sağlam ise E. Tümg. idiler) bu iki ismin istifalarının istenmesi karşısında ilk köpüren Evren oldu. Sadi Irmak’a hitaben gıyaplarında çok sert sözler sarf eden Evren'i Irmak sakinleştirdi. Selahattin Çetiner tarihe, İnönünün olaylı Kayseri gezisindeki hâdiselerde hükümetin tavrından rahatsız olduğu için istifa eden Kur. Bnb. olarak geçen şöhretli bir isimdi. ${ }^{63}$ Diğer taraftan Danışma Meclisi üyeliğinin yarattığı prestijden doymayanlar da vardı. Anayasa hazırlama işini geciktirip, bu şekilde üyelik süresinin olabildiğince uzamasını istiyorlardı. 1982 sonbaharında anayasayı halkoyuna sunmaya kararlı olan Evren, bir müddet sonra Danışma Meclisinin bu işi beceremeyeceğine inanmış ve konuyu MGK Hukuk Komisyonu-

59 Ellerinde veto kozu bulunan konsey, bunu hüküm haline getirmedi ama fiilen uyguladı.

60 Doğan, Dar Sokakta Siyaset, s.174.

61 "Buraya girenlerin listesini iyi tespit edin. Yarın demokrasiye geçiş döneminde bunlar yeniden sahnede görünmek isteyecekler. Politik hırsları bunları bize itecek. Zamanı gelince, ne yapacağımızı düşünürüz. Şimdilik siz bir tespit edin bakalım bu isimleri”. Doğan, Dar Sokakta Siyaset, s.174.

6227 Mayıs'tan sonra orduya dönen Çetiner, Kara Kuvvetleri Kurmay Başkanlığı'na kadar yükselmiş ve korgeneral rütbesinden emekli olmuştur. Bkz. M. Orhan Bayrak, Türkiye’yi Kimler Yönetti (1920-1984), İstanbul: Milliyet Yayınları, 1984, s.85.

63 “Treni Himmetdede’de Vali Muavini ve J. Kumandanı Tarafından Durdurulan İnönü Dün Kayseri’ye Sokulmak İstenmedi”, Akşam, 3 Nisan 1960. 
na da havale etmişti. ${ }^{64}$ Danışma Meclisi içinde bizzat konsey tarafından atananların fonksiyonu ise başkaydı. Bunlar, konseyden aldıkları talimatlar doğrultusunda önergeler veriyor; çoğu kez önergelerinin görüşülmesinin öne alınmasını yüksek sesle "Bu önerge aslında bizim değil MGK'nın önergesidir" diyebiliyorlard1. ${ }^{65}$

Nihayet Anayasa Komisyonunda hazırlanan metin Genel Kurula indiriliyor ve son şeklini alarak oya sunuluyordu. Dönemin kritik koşullarında 120 üye kabul; 7 üye red; 12 üye çekimser yönde oy kullanırken 17 üye de oylamaya katılmıyordu. Red oyu veren isimler şunlardı: Ertuğrul Alatlı, Mustafa Alpdündar, Abdulbaki Cebeci, Kamer Genç, Mehmet Pamak, Vahap Güvenç ve Feridun Şakir Öğünç. Bu üyelerin, Danışma Meclisinin kabulcüleri nezdinde gördükleri tepki inanılmazdı; hem Kamer Genç, hem de Mehmet Pamak âdeta istenmeyen adam ilân edilmişlerdi. Birkaç nahoş sahne yaşandı. Çekimserler ise retçilere saygılarını sunma yarışına girmişlerdi. Red oyu vermekten kendilerini caydıran olayın, tutuklanacakları yönünde tehdit edilmeleri olduğunu belirtiyorlardı. Beklentilerin aksine konseyin oylama sonucundan memnun olduğu gözleniyordu. 19 kişilik anti kabul cephesi, Danışma Meclisinin güdümlü olmadığının ispatı olarak, Avrupa kamuoyu nezdinde olumlu bir kanıttı. ${ }^{66}$ Danışma Meclisi artık tarihe karışmak üzereydi ancak bir isim vardı ki meclisteki görece muhalif tavır ve tutumları yüzünden siyasi geleceği tehlikedeydi: siyasi partilerin kurulmasına izin verildiğinde Muhafazakâr Parti’nin kurucu Genel Başkanı Mehmet Pamak. Nitekim Pamak, konsey tarafindan veto edilenler arasındaydı.

\section{Kaynakça}

Ahmad, Feroz. The Making of Modern Turkey. London, New York: Routledge, 2002. Akşam. "2. Cumhuriyetin Temeli Dün Atıldı. Devrimden 225 Gün Sonra Meclis Açıldı”. 7 Ocak 1961.

Akşam. “Treni Himmetdede’de Vali Muavini ve J. Kumandanı Tarafından Durdurulan İnönü Dün Kayseri’ye Sokulmak İstenmedi”. 3 Nisan 1960.

Aldıkaçtı, Orhan. Anayasa Hukukumuzun Gelişmesi ve 1961 Anayasası. İstanbul: İÜ HF Yayınları, 1973.

Altuğ, Kurtul. 12 Mart ve Nihat Erim Olayı. İstanbul: Baha Matbaası, 1973.

Bayrak, M. Orhan. Türkiye’yi Kimler Yönetti (1920-1984). İstanbul: Milliyet Yayınları, 1984.

Belge, Murat. 12 Yıl Sonra 12 Eylül. İstanbul: Birikim Yayınları, 1992.

Çetin, Celâlettin. İște Babıâli (Çuvaldızı Kendimize). İstanbul: Cem Yayınevi, 1991.

Danışma Meclisi Tutanak Dergisi, Cilt 1; 1’inci Birleşim 23 Ekim 1981 Cuma, Toplantı Y1l1 1981/1.

64 Doğan, Dar Sokakta Siyaset, s.179.

65 Doğan, Dar Sokakta Siyaset, s.180-181.

66 Danışma Meclisinin anayasa tasarısına çekimser oy veren Ağrı üyesi Paşa Sarığlu’nun, bu yöndeki reyi için Evren'in huzuruna çıkışı ve bir anlamda af talep etmesi karşısında Evren'in tavrı ve sözleri müşfikti. "Sizler cesaret edip tavır koymasaydınız, Avrupa'da onur kırıcı bir propagandaya yol açardı. Meclisten zorla geçen bir anayasa zannederlerdi. Onun için müsterih olun”. Doğan, Dar Sokakta Siyaset, s.186. 
Davison, Roderic N. Reform in Ottoman Empire 1856-1876. Princeton, New Jersey: Princeton University Press, 1963.

Dinçkol, Abdullah. Hukukun Temel Kavramları. İstanbul: Der Yayınları, 2002.

Doğan, Yalçın. Dar Sokakta Siyaset. İstanbul: Tekin Yayınevi, 1985.

Donat, Yavuz. Buyruklu Demokrasi 1980-1983 (Yavuz Donat'in Vitrininden-2). Ankara: Bilgi Yayınevi, 1987.

Evren, Kenan. Kenan Evren’in Anıları-2. İstanbul, Milliyet Yayınları, 1991.

Gözler, Kemal. Kurucu İktidar. Bursa: Ekin Kitabevi Yayınları, 1998.

Güran, Sait. "Yönetimde Açıllı". İdare Hukuku ve İlimleri Dergisi (Sarıca'ya Armă̆an). 3/1-3 (1982): 101-112.

Hale, William. Turkish Politics and the Military. London and New York: Routledge, 1994.

Hürriyet. “MGK, Gelir Vergisi Kanununda Değişiklikleri Görüştü”. 18 Aralık 1980.

Hürriyet. “Org. Saltık, Devlet Başkanlığı Genel Sekreteri Oldu”. 22 Eylül 1980.

Kahraman, Ahmet. “Bana Evren Paşa Deyin”. İstanbul: Boyut Yayınları, 1989.

Kahraman, Ahmet. Isşte Biz (Röportajlar ve Portreler). İstanbul: Kaynak Yayınları, 1984.

Kapani, Münci. Kamu Hürriyetleri. Ankara: Ankara Üniversitesi Hukuk Fakültesi Yayınları, 1981.

Karamustafaoğlu, Tunçer ve Mehmet Turhan. 1961-1982 TC Anayasaları (Karşılıklı Metinler) (1876, 1921 ve 1924 Anayasa Metinleri). Ankara: Savaş Yayınları, 1993.

(Kaya), Hasan Cemal. Tank Sesiyle Uyanmak (12 Eylül Günlüğ̈̈). Ankara: Bilgi Yayınevi, 1986.

Kaynar, Reşat. Mustafa Reşit Paşa ve Tanzimat. Ankara: Türk Tarih Kurumu Basımevi, 2010.

Kırmızı̈ül, Hüsamettin. Disiplin Suçve Cezaları ve Denetim Yolları. İstanbul: Kazancı Kitap Ticaret AŞ, 1998.

Küçük, Sami. “Atatürk ve 27 Mayıs”. Nusret Kuruosman, Çeşitli Cepheleriyle Atatürk (Seri Konferanslar), İstanbul: İstanbul Matbaası, 1964, 185-196.

Laçiner, Ömer. "Malatya Olayı-Türkiyedeki Faşist Hareketin Yapısı ve Gelişimi”. Birikim, 39 (1978): 15-19.

Milliyet. “Danışma Meclisi’nin hedefi: Yeni anayasa”. 17 Ekim 1981.

Milliyet. “Türk Meclisinde sağ taraf ağır basıyor”. 17 Ekim 1981.

Mumcu, Uğur. İnkılâp Mektupları. İstanbul: Tekin Yayınevi, 1993.

Mumcu, Uğur. Sakıncalı Piyade. İstanbul: Tekin Yayınevi, 1977.

Özbudun, Ergun. 1924 Anayasası. İstanbul: Bilgi Üniversitesi Yayınları, 2012.

Parla, Taha. Türkiye’de Anayasalar. İstanbul: İletişim Yayınları, 1991.

Resmi Gazete. "29 Haziran 1981 tarih ve 2485 sayılı Kurucu Meclis Hakkında Kanun”. 17386 Mükerrer Sayılı, 30 Haziran 1981.

Shaw, Stanford J. ve Ezel Kural Shaw. History of Otoman Empire and Modern Turkey. Volume II: Reform, Revolution and Republic: The Rise of Modern Turkey, 18081975. New York: Cambridge University Press, 2005. 
Soysal, Mümtaz. 100 Soruda Anayasanın Anlamı. İstanbul: Gerçek Yayınevi, 1997. Soysal, Mümtaz. Demokrasiye Giderken. İstanbul: Hil Yayın, 1982.

Tanör, Bülent. "Siyasal Tarih (1980-1995)”. Yay. Yön. Sina Akşin. Türkiye Tarihi 5: Çă̆daş Türkiye 1908-1980. İstanbul: Cem Yayınevi, 2000.

Tanör, Bülent. İki Anayasa 1961-1982. İstanbul: Beta Basım, Yayım Dağıtım AŞ, 1986.

Tanör, Bülent. Osmanlı-Türk Anayasal Gelişmeleri (1789-1980). İstanbul: Der Yayınları, 1995.ra

Turgut, Hulusi. 12 Eylül Partileri (Bir Dönemin Perde Arkası). İstanbul: ABC Ajansı Yayınları, 1986. 
İNSAN\&İNSAN, Yıl/Year 6, Sayı/Issue 19, Kış/Winter 2019, 79-97

DOI: https://doi.org/10.29224/insanveinsan.485775

\title{
The Constituent Assembly in Turkish Political Life
}

\author{
CENGIZ SUNAY
}

\begin{abstract}
In Turkey, there exists a recurring habit of directing and shaping political life. The prejudice that actors and their dependents in various fractions of society can be shaped by means of normative arrangements tends to claim that after every upheaval problems can be resolved with a new constitutional system. The willpower designing the Constituton 1982 is the most concrete example of this. 1982 Constitution gave primacy to a political system based on the representation of center shooting for precluding fractions defined by it as marginal via electon thresholds so as to ensure stability which lacks during the seventies. This study tackles the judicial base, foundation, working principle and member profile of the Constituent Assembly which is on the factory floor of the most contradictory Constitution of Turkey, namely the 1982 Constitution and which is about to outlive the 1924 Constitution as the most long-lasting constitution.
\end{abstract}

Keywords: Turkey's Constitutions, Constituent Assembly, 12 September Coup. 